\title{
Perspectives of Chinese students on studying MA Music programmes in a UK University
}

Elizabeth Haddon ${ }^{1}$

Music Department, University of York, UK liz.haddon@york.ac.uk 


\section{Resumo}

O interesse contínuo no ensino superior de música no Reino Unido a partir do mercado internacional levou ao aumento do recrutamento de estudantes da China e Hong Kong; no entanto, a bolsa de estudos acadêmica focada nesse contexto pedagógico não cresceu tão rapidamente quanto o número de alunos. Este estudo qualitativo contribui para a literatura que investiga as complexidades do ensino superior de música, percebidas por estudantes da China e Hong Kong que estão inseridos em programas de mestrado em música com duração de um ano em uma universidade do Reino Unido. Entrevistas semiestruturadas com nove estudantes internacionais de pós-graduação revelaram informações sobre seus estudos anteriores na China e Hong Kong, sua escolha pelo programa no Reino Unido, apoio familiar, planos futuros e pontos de vista sobre estudos acadêmicos e de desempenho em diferentes países. Os alunos discutiram os desafios de estudar no Reino Unido em relação às habilidades de linguagem, pensamento crítico e grupo de colegas, mas também identificaram a expansão do repertório, a individualidade no desempenho, 0 acesso a uma ampla gama de recursos, instalações e oportunidades, e o relacionamento do supervisor como experiências positivas de aprendizado. Resultados relacionados ao pensamento autônomo, ensino acadêmico e de desempenho, autenticidade e atuação, e potencial pedagógico são relevantes para os educadores.

Palavras-chave: Internacionalização, ensino superior de música, estudantes chineses, pedagogia

\section{Abstract}

Continuing interest in higher Music education in the UK from the international market has led to increased recruitment of students from China and Hong Kong; however, academic scholarship focusing on this pedagogical context has not grown as swiftly as student numbers. This qualitative study contributes to literature investigating the complexities of higher Music education as perceived by students from China and Hong Kong undertaking one-year taught Music MA programmes at a UK university. Semi-structured interviews with nine international postgraduate students revealed information about their previous studies in China and Hong Kong, their choice of UK programme, family support, future plans and views on academic and performance study in the different countries. Students discussed the challenges of UK study relating to language skills, critical thinking and the peer group, but also identified expansion of repertoire, individuality in performance, access to a wide range of resources, facilities and opportunities, and the supervisor relationship as positive learning experiences. Findings relating to informed independent thinking, academic and performance teaching, authenticity and agency, and pedagogical potential are of relevance to educators.

Keywords: Internationalization, higher music education, Chinese students, pedagogy

1 Senior lecturer, Programme Leader, MA Music Education: Instrumental and vocal teaching, Music Department, University of York. 


\section{Introduction}

Many UK higher education institutions have experienced an increase in applications from international students, particularly for taught MA programmes. In 2014 The Higher Education Funding Council for England reported "almost equal proportions of UK and Chinese students in full-time taught masters programmes" with $26 \%$ UK and 23\% Chinese students on these programmes (HEFCE, 2014). Sustained interest from overseas students is shown by figures for taught postgraduate programmes in 201718: $47 \%$ of full-time students were UK domiciled; $43 \%$ were non-EU domiciled and $11 \%$ were other-EU domiciled; for overall higher education in the UK, 2017-18 saw a 21\% rise in students from China compared to 2013/14 (HESA, 2014), and in 2017-18 "one-third of all non-EU students were from China" (HESA, 2019). Hong Kong is also in the top five non-EU countries sending students to the UK for Higher Education (UKCISA, 2019). While no statistics are available on those currently studying Music at postgraduate level, the expansion of the Chinese economy, combined with concerns for optimum opportunities and competition for graduate jobs in China (RASTALL, 2009) has led to continuing interest from this market. Although extensive literature on internationalization has examined issues for overseas students and their teachers in higher education, particularly in university contexts, there is little research on the experience of Chinese students studying Music overseas at higher education level. The lack of scholarship relating to Music study is asynchronous with the growing demand for UK Music education from this market; this research contributes to addressing this void through investigating the perceptions of a sample of students from China and Hong Kong enrolled on taught MA Music programmes at a UK university. The study is contextualized through discussion of music education in China and Hong Kong, illustrating challenges that students and educators face within school and higher education, which connect to issues of internationalization.

\section{Music education in China and Hong Kong}

Music education in Chinese schools varies considerably, despite education reforms designed to implement compulsory music courses for primary and secondary schoolchildren (XIE; LEUNG, 2011). The globalization of China has resulted in a situation where "music promoted by Chinese authorities for use in classrooms attempts to incorporate diverse musical cultures and to encourage world peace", but concurrently "music education is used to perpetuate ideologies of political socialisation, to promote the historical heritage of traditional Chinese music, and to reproduce Chinese nationalism" (LAW; HO, 2011, p.373). In schools, provision and delivery have been hampered through "teachers' insufficient content knowledge and inadequate teaching materials" (HO, 2014, p.284) and by "unqualified music teachers, insufficient teacher training, and over-emphasis on the 'main academic subjects' (such as literature, languages and mathematics)" (XIE; LEUNG, 2011, p.64). Music teachers in Shanghai have experienced difficulties in designing teaching activities, and many Shanghai and Hong Kong teachers 
indicated that their materials were "neither up-to-date nor adequate" (HO; LAW, 2006, p.226).

Although the Chinese school curriculum has defined Music as "an essential part of humanities and quality-oriented education" (XIE; LEUNG, 2011, p.64) the same authors identify "negative perceptions of students and parents on school music education" (ibid). Music may be perceived as of little value for employability, despite sometimes being viewed as an "enrichment activity" potentially aiding students to gain a university place. In Hong Kong, which has a structure of highly competitive public examinations in which "only the top 20\% succeed in reaching tertiary level" (WHITBREAD; LEUNG, 2011, p.6), secondary school students have regarded Music "as the subject for which their motivational orientations, their perceptions of importance, the price of success or failure, and their beliefs about their parents' evaluations and expectations, are all, on average, the lowest" when compared with Chinese, English, Mathematics and Liberal Studies (WHITBREAD; LEUNG, 2011, p.15). Leung and McPherson have defined Music in schools in Hong Kong as "at risk" (2011, p.69), reporting that Music has not been offered in the Hong Kong Advanced Level Examination for university entrance since 2007; these authors also found that students' interest in Music education declines in secondary school (LEUNG; MCPHERSON, 2010) as students prioritize subjects relevant to their careers. ABRSM ${ }^{2}$ Grade 8 performance certificates are viewed as beneficial to those who desire to study at an "elite" secondary school in Hong Kong, as this context for study "is thought to 'guarantee' or enhance entry into universities" (LEUNG; MCPHERSON, 2010, p.165); however, this may not be with the aim to study Music: Music is viewed as "risky" as a profession, and "it is considered that becoming a musician does not enhance students' opportunities for gaining a position with a high income, high social status or good career opportunity" (ibid).

Leung and McPherson have identified that in addition to difficulties relating to perceptions of the value of Music which have an impact on uptake of study, there are also issues concerning the curriculum, which they argue needs to move from a functional focus of skills and knowledge assimilation to "authentic experience that involves creating, listening to and performing music" (LEUNG; MCPHERSON, 2010, p.165). These aspects of value and motivation may influence students' and parents' views on the value of Music, and may be connected to perceptions of genre enjoyment and validity: Ho and Law (2006) found preferences for Western classical and popular music among students from Hong Kong, Shanghai and Taipei; however, Petersen (2018) identified that students feel there is less acceptance of jazz and rock than of classical music in China. Ho's analysis of the views of 2971 secondary school students in Beijing revealed that while teachers acknowledged the need for a balanced curriculum including Western and Chinese classical and popular music, they would prefer a "more open and culturally diversified curriculum" containing more popular music and music from other cultures (HO, 2014, p.283). Although curriculum changes in China and Hong Kong have enabled the inclusion of Western music and popular music, teachers may have felt ill-prepared to

2 Associated Board of the Royal Schools of Music: https:/gb.abrsm.org/en/our-exams/ 
teach these genres (YANG et al., 2010); teachers in Hong Kong recognized the value of a multi-cultural approach to school music education but stressed the difficulties and the limitations of their ability to deliver this (HO; LAW, 2009). Teachers have noted a lack of guidelines for teaching popular music and some expressed concern that their choice of material might not be accepted by the school or by the Chinese authorities (HO, 2014). Hong Kong teachers with Western classical music backgrounds have also been expected to teach Chinese music (COLLEY et al., 2012). These findings suggest challenges for music educators and for students in China and Hong Kong; nevertheless, considerable numbers of students manage to study music to a sufficiently high level to enable them to complete undergraduate music degrees in China and Hong Kong and then progress to overseas postgraduate music study. However, it is clear that students from these countries may possess divergent musical and pedagogical experiences; these could influence their subsequent learning.

\section{Internationalization}

Internationalization has become an increasingly significant agenda for UK higher education institutions. As articulated in detail elsewhere (e.g. WATKINS; BIGGS, 1996; 2001; COVERDALE-JONES; RASTALL, 2009; WANG, 2015; SKYRME: MCGEE, 2016) the consequences of this orientation have considerable impact on students and teachers, particularly relating to adjustment to/of pedagogical practices, social and cultural integration, academic and pastoral support and career relevance. Currently, mobilization policies of the UK and Chinese governments support Chinese students' study abroad, with the Chinese aim that "a large number of talents shall be cultivated that are imbued with global vision, well-versed in international rules, and capable of participating in international affairs and competition" (Chinese Government: Outline of China's National Plan for Medium and Long-term Education Reform and Development (2010-202), cited in HUANG, 2016, p.184). Currently, there is insufficient evidence to ascertain correlation between governmental and individual/family aspirations for the acquisition of these capabilities, and even less information on the awareness of teachers in higher education in other countries of this policy; however, various factors influencing motivation to study abroad have been investigated.

The "push-pull" factors identified by Mazzarol and Soutar (2002) in relation to Chinese students' decision to study overseas include "push" factors comprising perceptions of superior quality at the overseas institution; difficulty in gaining entry to a local programme or lack of appropriate local programme in the home country; aspirations to "migrate after graduation" (p. 88) and "desire to gain a better understanding of the 'West'" (ibid). "Pull" factors include the reputation of the overseas country and institution, recommendations from family, friends, agents and other contacts, tuition fees, living and travel costs, environmental factors including climate, study culture, safety and racial discrimination, and prospects after graduation for immigration. Bodycott (2012) extended this work to explore the views of parents as well as students in mainland China 
and found that students were more interested in "tangible features" of the overseas programme, institution and country, such as higher quality education and "international/ intercultural experiences" (p.359) whereas parents were "more concerned with future benefits, support provided and costs associated with study abroad" (ibid, p.366). Reputational aspects including institutional ranking and quality were also identified in relation to Chinese music students' selection of a rural research university in the US for their degree studies (YAKABOSKI; RIZZOLO; OUYANG, 2017).

Bodycott (2012) identified students' criticisms of higher education in mainland China, involving concerns relating to inflexibility of programmes, un-progressive teacher-centred pedagogy and lack of international programme focus. These resonate with other findings emphasizing students' frustrations with exam-focused education and lack of active participation in classroom environments (YIN; HAN; LU, 2017); factors which may influence the decision to study abroad. Nevertheless, negotiating the contrasts between familiar and new educational practices can be daunting for students. Even within a local higher education institution such as a Music department at a Hong Kong university, where commercialization, quality assurance and internationalization have resulted in curriculum reform, home students are likely to experience considerable demands in order to be "proficient with theory and history, performance, composition, pedagogy, administration and production" (HO, 2001, p.193). Studying abroad adds further complexity, particularly in regard to negotiating teacher-student relationships, language skills and learning strategies, concerns relating to over-reliance on co-national peers and difficulties in forming relationships with other students, and anxieties concerning health, finances and academic success (MCMAHON, 2011).

Ho suggests that "the ultimate goal of music education from the 'learning perspective' is to stimulate self-directed learning in formal and informal education" (HO, 2001, p.193); however, pedagogical research has identified tensions between expectations of self-and teacher-directed learning as one of the primary sources of pressure for Chinese students studying abroad: educators' "attempts to foster autonomous learning are often perceived as unfriendly and uncaring" (EDWARDS; RAN, 2009, p.193). Evans' account of conservatoire music study in China reveals that:

Teachers rarely depart from approved texts, or refer to conflicting theories within their subjects. A student who cites views different from the course teacher's is more likely to be regarded as tactless or unnecessarily inquisitive, than as showing legitimate academic curiosity and initiative (EVANS, 1995, p.110).

More recent research suggests that Confucian concepts of $\mathrm{Li}$ (the manner between teacher and student, involving respect and regard for the teacher and for authority) and Wù (reading and memorization of texts) within the collectivist culture (LI; RIVERS, 2018) remain strongly prevalent within Chinese education; the concept of 'face' additionally "discourages critical and argumentative discussions and joint construction of knowledge in class" (ibid, p.790), as "it would be considered disrespectful to challenge what a teacher says in a Chinese educational context" (ibid, p.795) and students do not 
want to feel shame or embarrassment, or cause it for others through giving incorrect answers or asking an "inappropriate question" (ibid). Brand's observation of students in Hong Kong indicates that "the years of classroom conditioning, passively sitting silently, smiling, and memorizing, made it difficult to do the very things so important in learning - formulating a position, discussing, questioning, and arguing" (BRAND, 2006, p.80). According to Holmes (2004, p.296) students may find "the Western classroom practices of volunteering answers, commenting, interrupting, criticizing, asking questions, or seeking clarification ... as bold and immodest". Therefore, engagement in Western learning contexts may create "learning and communication dislocations" (ibid) which can mean that Chinese students are "disadvantaged" and "differentiated" from home students (HOLMES, 2004, p.303). Negotiating the transition from a culture emphasizing hierarchical teacher-student relationships to one in which students are expected to question material, viewpoints and practices is challenging, particularly as the practices of Chinese music education appear to promulgate hierarchical and deferential pedagogy. The tensions of subject content as well as issues of resources and teacher support may have implications for alignment of content and practice when students embark on subsequent programmes of study.

While there is a lack of comparative research on learning music at higher education level, Petersen (2018) undertook comparison of a small sample of Chinese and Swiss university music students, finding similarities between their career aims, their views on the role of the teacher, which included the teacher as friend and "role model/mentor" (p.235), and on the relationship between ability levels, effort and talent. Both Swiss and Chinese students expected to find working in the music profession challenging. Chinese students appeared to have had fewer pre-university opportunities for ensemble playing; they received greater musical support from their family during their university study, and appeared to value more strongly concentration on subject-specific knowledge, rather than more holistic contextual understanding which could arise through non-music activities and relationships. Petersen relates this last finding to the value placed upon high-level instrumental technique in China and the pressure to concentrate on relevant activity to develop this in order to succeed in a competitive environment.

Pedagogical literature has demonstrated interest in comparing teaching techniques and broadening the perspectives of Western educators and those in China and Hong Kong through shared practice and cultural exchange (WATERS, 2014). As yet, this field remains under-developed. The research findings relating to music education in China and Hong Kong suggest that a number of tensions exist within school and university music education relating to teachers' and students' views of learning, pedagogical practices, genre, resources, support and opportunities. The findings concerning internationalization indicate further concerns relating to programme availability, institutional reputation, quality, cost, curriculum content, pedagogical practices, and integration. This research contributes to understanding of these complexities through investigating the perceptions of a sample of students from China and Hong Kong studying Music at postgraduate level in a university in the UK. 


\section{Method and participants}

This research investigated how participants regarded learning at the UK institution, probing their reasons for the choice of programme, the influence of family support and previous academic studies, views on academic and practical studies, and the challenges involved. The study took place in a UK university music department and involved students enrolled on various one-year taught MA Music programmes, with contact time of approximately four hours per week during three ten-week terms and reduced contact time during the summer study period prior to submission of their final piece of work (recital or extended essay). A minimum IELTS ${ }^{3}$ score of 6.0 was required for admission, in addition to a 2:1 undergraduate degree in Music. Following ethical approval from the university, all students from China and Hong Kong enrolled on these programmes during one academic year received an email detailing the project and inviting them to participate.

Nine students responded, all female (there were no overseas male students in the cohort) aged 23-27, studying various programmes: Piano Studies (3), Community Music (3), Music Technology (1), Music Performance (1) and Research (1). Two participants were from Hong Kong, the rest from mainland China (see Table 1 for details). Of the nine students, one had previously gained a BA (Hons) degree in the same UK music department and also possessed experience of UK GCCE and A-levels. Another student was completing an MA by Research following an MA in Community Music from the same music department; one student had gained a Music MA in China and another already held two MA degrees in Economics (Australia) and Music (Hong Kong). This range of experience is valuable; increased mobilisation of students may result in greater diversity of study locations and programmes; this provides depth of perspective on the study questions. All of the remaining students came to the UK direct from undergraduate degrees in China.

\begin{tabular}{|l|l|l|l|l|l|}
\hline Participant & Age & UK MA course & $\begin{array}{l}\text { Country of } \\
\text { origin }\end{array}$ & Previous study & Career goal \\
\hline S1 & 23 & $\begin{array}{l}\text { Community } \\
\text { Music }\end{array}$ & China & $\begin{array}{l}\text { Undergraduate } \\
\text { degree (China) - } \\
\text { Music Education }\end{array}$ & $\begin{array}{l}\text { Classroom music } \\
\text { teacher, China }\end{array}$ \\
\hline S2 & 24 & $\begin{array}{l}\text { Community } \\
\text { Music }\end{array}$ & China & $\begin{array}{l}\text { Undergraduate } \\
\text { degree (China) - } \\
\text { Recording Arts }\end{array}$ & $\begin{array}{l}\text { Work to fund UK } \\
\text { PhD study, then } \\
\text { classroom music } \\
\text { teacher, China or } \\
\text { music therapist, } \\
\text { China }\end{array}$ \\
\hline
\end{tabular}

3 IELTS: International English Language Testing System. 


\begin{tabular}{|c|c|c|c|c|c|}
\hline S3 & 23 & $\begin{array}{l}\text { Community } \\
\text { Music }\end{array}$ & Hong Kong & $\begin{array}{l}\text { BA (Hons) Music, } \\
\text { University of [X], UK }\end{array}$ & $\begin{array}{l}\text { Community music } \\
\text { work in UK or Hong } \\
\text { Kong }\end{array}$ \\
\hline S4 & 26 & $\begin{array}{l}\text { MA Music } \\
\text { (Piano Studies) }\end{array}$ & China & $\begin{array}{l}\text { Undergraduate } \\
\text { Music degree } \\
\text { (China) - Piano } \\
\text { Performance, and } \\
\text { Piano Performance } \\
\text { MA (China) }\end{array}$ & $\begin{array}{l}\text { Classroom teacher } \\
\text { in a middle school } \\
\text { or piano teacher in } \\
\text { China }\end{array}$ \\
\hline S5 & 25 & $\begin{array}{l}\text { MA Music } \\
\text { (Piano Studies) }\end{array}$ & China & $\begin{array}{l}\text { Undergraduate Music } \\
\text { degree (China) - } \\
\text { Piano Performance }\end{array}$ & $\begin{array}{l}\text { Piano teacher in } \\
\text { China }\end{array}$ \\
\hline 56 & 23 & $\begin{array}{l}\text { MA Music } \\
\text { (Piano Studies) }\end{array}$ & China & $\begin{array}{l}\text { Undergraduate Music } \\
\text { degree (China) - } \\
\text { Piano Performance }\end{array}$ & $\begin{array}{l}\text { University piano } \\
\text { teacher in China }\end{array}$ \\
\hline S7 & 26 & $\begin{array}{l}\text { MA by } \\
\text { Research }\end{array}$ & China & $\begin{array}{l}\text { Undergraduate Music } \\
\text { degree (China) - } \\
\text { Musicology; MA in } \\
\text { Community Music } \\
\text { (University of }[X], \text { UK) }\end{array}$ & $\begin{array}{l}\text { UK PhD, then } \\
\text { possibly establish an } \\
\text { agency or work in } \\
\text { artistic management } \\
\text { in China } \\
\end{array}$ \\
\hline 58 & 27 & $\begin{array}{l}\text { MA Music } \\
\text { (Vocal } \\
\text { Performance) }\end{array}$ & Hong Kong & $\begin{array}{l}\text { Undergraduate Music } \\
\text { degree (Hong Kong), } \\
\text { MA in Economics } \\
\text { (Australia), MA in } \\
\text { Music (Hong Kong) }\end{array}$ & $\begin{array}{l}\text { Vocal performer, } \\
\text { Hong Kong/China }\end{array}$ \\
\hline S9 & 23 & $\begin{array}{l}\text { MA Music } \\
\text { Technology }\end{array}$ & China & $\begin{array}{l}\text { Undergraduate Music } \\
\text { degree (China) - } \\
\text { Music Management }\end{array}$ & $\begin{array}{l}\text { UK PhD, then } \\
\text { Lecturer in a Chinese } \\
\text { university }\end{array}$ \\
\hline
\end{tabular}

Table 1: Participant information

Semi-structured one-to-one interviews were conducted in English with the researcher, who is British, and is a member of academic staff at the UK institution. The researcher was aware of the potential for cultural bias and sought to avoid giving any indications of personal preferences or value judgements relating to context of study, programme content, engagement and values, during the interviews. The questions were constructed following with discussion with colleagues delivering MA teaching and through consideration of literature discussed above, and although open-ended, were phrased as simply as possible and designed to elicit responses concerning reasons for choosing the course; the students' prior learning experiences; comparison between these and learning in the UK; support for learning; self-view, and the value of the UK learning experience. The interviews lasted between 40 and 75 minutes and took place at the end of the 12-month programme just after submission of the final piece of work. 
Transcriptions were sent to individual students for checking and they were encouraged to add further information. The data were subsequently analysed by hand through iteratively coding the transcripts to elucidate themes, according to procedure detailed by Braun and Clarke (2006). While the small sample precludes generalizable findings, it contributes to enhancing understanding of Chinese students' views of learning and reasons for engaging with UK postgraduate Music programmes. Where students are quoted in the text below, they are identified by participant number as in Table 1.

\section{Findings}

The findings are discussed within the following sections: programme choice; family support and undergraduate studies; student views on studying in China, Hong Kong and in the UK: academic studies; performance studies; and challenges experienced by students from China and Hong Kong.

\section{Programme choice}

Students expressed motivation to study in the UK because of its positive "academic atmosphere" [S9], and stated that "for Chinese students the most important thing for choosing university is the ranking, ranking in the world and in the UK" [S2]. Therefore, the university's position within the top 20 in the UK was significant. Two students applied after meeting programme leaders and administrators on a visit to China; one had a connection via a former teacher who recommended the course following take-up by previous students. These connections enabling application to the programme correspond to those of students in research by Yakaboski, Rizzolo and Ouyand (2017). Those studying Community Music noted a lack of comparable programmes in China and Hong Kong, and the appeal of the flexibility of module choice. Furthermore, most said that in addition to enhancing employment prospects the MA would accelerate their progress, academically and financially, as MA programmes in China and Hong Kong tend to be of two or three years duration"; one student noted that "it's really important to come here, because it will not be too much progress in China because it's all kind of the same and the time is longer; here is really effective for me and a really different learning experience" [S6]. While Choi (2012) found that the most influential factors for East Asian international students' choice of music programme in the United States were the reputation of the professor and programme, and scholarships, these students also noted the programme duration and content. Choi's respondents appeared less concerned with breadth of cultural experience and were more concerned to gain specialist subject knowledge.

4 See https://www.scholaro.com/pro/countries/China/Education-System for further details on the duration of the levels of study within the Chinese education system. 
In addition to improving their English language skills, these students hoped to broaden their cultural awareness, some using the UK as a base for European travel; they wanted to become more independent, to develop friendship skills and more able to accept different viewpoints. It was felt that as piano is a Western instrument, studying it in the UK might provide "more original methods" [S6] than in China; likewise, classical singing was connected to its European heritage [S8] and jazz to Western expertise [S2]. It was noted that there were few jazz teachers in China, so the UK was a better place to support this interest [S2]. These correspondences of music and expertise were also expressed by Chinese students choosing to study Western music in an American university (YAKABOSKI; RIZZOLO: OUYAND, 2017). The UK participants hoped to gain theoretical and practical understanding of their subject, to develop leadership, communication and fundraising skills (Community Music), and noted the appeal of the practical nature of the Performance and Piano Studies programmes and the opportunity to participate in many ensembles.

\section{Family support and undergraduate studies}

All nine students acknowledged financial and emotional support from their families. Most had no siblings and were the first in their family to study overseas; they mentioned that their parents understood the importance of the UK qualification, the quality of the degree and its subsequent value to the student and therefore to the family, and the importance of breadth of experience. Huang (2012) observed that Western classical music can be perceived as a tool for social mobility; Comeau, Huta and Liu (2014) and Petersen (2018) recognized the support of the family for those learning music; participants in Petersen's study revealing the importance of grandparents as well as parents to their music study. In this research, students' families financed extra English tuition to help them achieve the IELTS qualification, and helped them find advisers and guidance on studying abroad.

It was thought that "many parents encourage their children to study piano, singing and other instruments in China. They regard music as an interest or something beneficial to children's development" [S2]. The parents of those participating in this study seemed positive about the value of music as a career; although S8, who previously studied Economics, explained that she had to convince her parents:

Actually they rejected me to do a music course in the past, but I just showed them my endurance, my effort, and they just want to send me for completing my dream. They don't have a lot of expectations for me, at this moment, but they have already seen my efforts and my progress so they are happy about that.

This student felt that:

As I'm happy about my study or my career path they think it's alright. I want to go back and find a normal office work that's not badly paid and then I can have 
spare time to do any performance and just change to a music path like music teaching or singing teaching, gradually, and they also accept such a thinking.

However, she also thought that:

Normal people will find music not a good career. The music students ... mainly go to small music shops to teach children ... and they don't think it's a very good career, but my singing teacher said music is a good career now, especially singing - 'you won't be starved!' [S8].

Several students thought that the "best choice" of music career possibilities in China is to be a university teacher or performer; however, "not every student can be a university teacher" $[\mathrm{S} 1]$ as this requires a $\mathrm{PhD}$, even for instrumental or vocal teaching. Therefore, many music graduates work in primary or secondary schools where salaries are "relatively low" [S1], but "it's hard for music students to find jobs they are satisfied with in China" [S1] due to the amount of competition. Most participants mentioned the financial cost of their UK studies and hoped to get a job in which would enable them to reimburse their parents for some of their UK fees and living expenses.

Students' discussion of their previous study helps to contextualize their transition to UK study. Their accounts of undergraduate study in China and Hong Kong indicate a highly competitive selection process in which applicants decide on a specialism such as musicology, composition, education or music production and must pass several levels of examination in the specialist area plus other subjects in order to gain a place. For conservatoire study there were three levels:

\footnotetext{
You pass the first, then you go to the second, then several tests are together, you pass the second, then you go to the third, and after you finished the third they will tell you that you passed the arts part of your examination, then you go to the study part - your Chinese, maths, English, everything, then you need to put them together to go to a conservatory [S7].
}

These students reported that their Music degree consisted of three years of compulsory and elective modules and a fourth year concentrating on a dissertation. Performance students received weekly one-to-one lessons in addition to lectures, and their recitals of etudes and standard Western classical repertoire were assessed by a panel of around eight piano teachers two/three times a year. All students studied numerous compulsory courses which included Western and Chinese music history, analysis, teaching, harmony, plus English, politics, Chinese literature and mathematics and other subjects. Passing the courses was essential: "I remember in my year 2 or 3 , in a week I've got seven essays to write ... you need to get the credits from optional courses" [S7]. The main subject and other compulsory courses were assessed by termly formal examinations. While options of examination or essay existed, the choice was the prerogative of the lecturer, not the student: "the most important evaluation method in China is examination" [S2]. These also applied to the performance masters courses in China; S4 reported the pressure of increased examination attainment requirements for each term, 
being required to pass with a mark higher than $60 \%$ in the first semester, then over $70 \%$ and over $80 \%$ in subsequent semesters.

In relation to their Chinese undergraduate and masters courses, these students experienced large lecture groups of 20-300 students which reinforced the power of the teacher and inhibited group discussion. Only rarely would students observe the work of their peers: most learning seems to have taken place as an individual within the group setting, or in isolation in practice rooms. These students reported having an academic supervisor only in the fourth year of undergraduate study or the third year of masters study for the dissertation; they would have appreciated more individual support, and felt that "in China we have too many students in universities and the teaching resources are sometimes limited" [S2].

These comments suggest that music students in China and Hong Kong are expected to maintain a rigorous approach to study within a pressurized and competitive environment, supported by their families but at the same time aware of the importance of their success to the whole family. Their comments indicate extensive time spent on subsidiary subjects to gain entry to higher education as well as the continued importance of successful results in these to complete a Music degree.

\section{Student views on studying in China, Hong Kong and at the UK institution}

a) Academic study: cohort size, supervisor relationship, feedback and facilities

These students described study at the UK institution as more advanced than comparable programmes in China, and highlighted the relevance of programme content. The small size of the UK institution's cohorts (maximum 12 students for this sample) was deemed positive, giving "more time to discuss, to have interactions with your lecturer or other students" [S3]; therefore, "I learned much more than I supposed within one year" [S9]. Their study at the UK institution changed their perceptions of study in China: "Chinese students should be encouraged to have more group discussion and group activities" [S2], with greater peer cooperation and teamwork.

Several students mentioned the support of UK departmental administrative staff and of their supervisor: "my supervisor helped me a lot ... but if I'm in China I can't talk to my tutors so many times, I can't improve my knowledge very quickly" [S9]. One student from Hong Kong noted increased individual supervision in this institution, which contrasted with her previous Music MA in Hong Kong, where she felt "no one will care about your progress; you just submit your assignments" [S8]. Students also appreciated the relative informality of the UK student-supervisor relationship: "the teacher with the student here is so family, just like friends, but in China it's so different ... not very close" [S1]. The supervisors in the UK institution gave "many instructions and suggestions" [S2]; "always give me some ideas" [S1], might find resources, and "always show a positive attitude toward my essays or ideas - he gives me much confidence" [S2]. This suggests a 
mentoring style of relationship as advocated by Leong (2010); additionally, perceptions of high expectations from staff for both research and performance provided increased motivation. Students also noted the importance of personal feedback from their UK supervisor: "I like the report here, where we get feedback, we know where we can improve, it's very important for us, but we don't have this in my university in China" [S5]. In China, students were awarded a numerical pass or fail mark, with no additional information. The detailed individual UK feedback was valued.

Students appreciated facilities including the 24-hour library and the department's studios and collection of instruments, which included harpsichords, fortepiano and organs. The facilities also enabled a more practical approach to learning than previously; for example, gamelan and African drumming workshops in the Community Music MA created holistic understanding, rather than purely abstract knowledge of the instruments, such as their range and notation requirements [S7].

\section{b) Performance studies: teaching and repertoire}

Differences emerged between these students' experience of performance studies in China and Hong Kong and at the UK institution, both in one-to-one lessons and in the taught programme content. During their UK MA, performance students received regular one-to-one lessons with a piano/vocal teacher plus weekly group sessions and individual tutorials with their programme leader, who also oversaw and coached performance, and helped them prepare for their termly assessed recitals, each requiring a written commentary. It was felt that studying in this UK music department "helps you become a more academic player" [S6]:

In China it was more about patience with techniques, but I think [there] it ignores a lot of stuff like detail about piano practice, or listening, and pedalling, or fingering, or other very tiny problems, which is kind of important parts within piano practice [S6].

This student expanded on her comment: "here, practice is more complicated ... I've learned lots about hearing, pedal, or the finger legato and the music tone - the different ways for touching the keys" [S6]. This was informed by listening to recordings, and through recording oneself and listening back [S6]. This student observed: "here you need to be thinking ... more about the musical expressivity and the character and the composer's instructions and the structure". In China, the "teacher will give you some suggestions and she will say 'I like that' or 'I don't like that' or 'I wouldn't do that' or 'I'd change that'" [S4]; this student thought that her UK teachers "have absolutely higher requirements for how you deal with music, how you understand and get the appropriate understanding for the music, and especially musical expressivity".

Furthermore, the UK course gave students a new outlook on repertoire. Previously, repertoire was almost always chosen by the teacher [S1, S2, S4, S6] and usually focused on the "most popular composers" [S6]; those who had some freedom in choosing rep- 
ertoire noted their choices were closely moderated by their teachers [S3, S5]. Students felt that all pianists would "play almost the same; the only process they learn is piano" [S6]; it was difficult for them "to be more detailed or more individual" so they were "routine" [S6], whereas on this MA course students realized that "we need to think more so that you have got your own style" [S6]. Previous repertoire for these pianists comprised Western classical pieces, particularly those by Bach, Chopin and Liszt, and some hybrid compositions including piano versions of traditional Chinese music. One student discussed the expansion of her repertoire through playing contemporary music in the UK institution's piano ensemble: "At the beginning it was really weird or abstract for me to understand but ... I can handle it a little bit now" [S6]. This provided "something different, unique" [S6]. Conversely, another pianist expressed reservations about contemporary music: "I don't like it! And I'm not that good with ... complicated fingerings and rhythmic patterns ... [I've] not yet quite got the mental preparation for accepting these things" [S4]. While one student thought that Chinese teachers acknowledged the importance of new repertoire, it was also suggested that "one thing that [Chinese] teachers don't want to teach is the new pieces because they don't have that much knowledge about [them]" [S5] and therefore "in China the contemporary music is really rare" [S6]. The UK institution provided a chance to expand repertoire; it also could contribute subsequent distinctiveness when students returned to a culture where "we've got too many Chinese piano students" [S6].

While performance was seen to be "really demanding here, much more than before" [S6], and to require considerable daily practice, it was deemed positive. Students thought that staff took time to explain, clarify and encourage all aspects of performance, and had elevated students' learning: "they really help you to find your potential" [S4]. One student taking piano lessons alongside her Community Music MA remarked: "when I come to here at first I feel so totally different but now I really love here, I love this style" [S1]. Another student also mentioned participating in performance workshops which included sessions on performance anxiety: "I think my previous singing teacher may ignore this problem! But here [through these opportunities] ... I think I have more confidence and less anxiety" [S8].

These comments suggest that these students developed understanding of both the musical works and of their approaches to learning. Although they experienced less focus on technique than in China, students were expanding their repertoire and developing creative, critically informed interpretations with greater awareness of individuality, and of strategies to support performance. Further research would be needed to determine whether these findings would be representative within a larger sample, working with a greater range of teachers, and whether these differences are the result of progression from undergraduate to MA level, or whether they would also be present in China when comparing undergraduate and MA study. 


\section{c) Challenges experienced by students from China and Hong Kong}

Despite the positive factors of opportunities and contact with staff, students experienced academic challenges: "it is not easy to get high marks in UK because of different language, thinking pattern and the rigorous academic atmosphere in UK". Participants felt that "the way of thinking is quite different" [S5] and required considerable adjustment, as well as the development of focus and independence: "normally in China ... the teacher will tell you what you should do now, and what you should do next ... but here it's totally your business and you need to keep the rhythm of the study" [S4].

Those studying performance also noted expansion of their conception of learning: "in China ... the teacher always teaches the student how to play it but only the technical part, not so many critical thinking" whereas "here is more focused on the details, and so many different ways, different angles to think about the music, but in China there's not so many ... paths to choose" [S5]. These students delineated a predominantly instructive approach to their previous performance tuition in China: "[the] teacher will say "do it like this way" and they play that for you and then you imitate ... in China we just follow the teacher" [S4], whereas in the UK institution they needed 'informed knowledge' and to develop independent thinking:

In China, the teacher will focus on some technical problems ... for the musical expressivity they always give you some clear suggestions, like this is where you need some more space or there you need to keep flowing, but normally they won't spend too much time about why you need more space or what is the music style and what is the character ... they won't explain much ... but in here, we need to be thinking about that independently! [S4]

This approach was welcomed: "I haven't had this class in China, and for me it's really fresh and kind of demanding" [S6]. A singer was also encouraged to take a more holistic and scholarly interest in her music:

My singing lessons in Hong Kong focused more on the technical skills instead of any interpretations but here [my teacher] always explained what the lyrics are about and how I should ... position myself into the piece; what character ... it's more about understanding of the piece and how to interpret it ... [and] about improving my vocal skills, so it's more all-rounded here. [...] now I think a lot about how I should interpret the song in a ... meaningful way, more closer to the composer's [intentions] ... there are a lot of informations that I have to know after doing my degree here! [S8]

While students noted that the course leader "taught us a lot about the creativity thinking, or more interpretation of ideas, and I think this helps me a lot" [S6], they also expressed expectations of greater input from themselves: "here I think you need to think more about your pieces, or more about the creative or sometimes even critical or interpretation ideas" [S6]; which extended to "the interpretation ... the marks, are they more the composer's intentions, or the player's?" [S6]. Playing instruments previously unavailable to these students such as the harpsichord and fortepiano could develop 
"inspiration", as "you cannot put too much force in there ... I will [consider] ... the sound and the dynamic range ... it gives me quite a precious experience" [S4]. Consequently, "another thing I learned here is I know why I play like that way ... maybe because of the instrument" [S5]. Therefore, historical and procedural awareness contributed to developing performative understanding.

This process was supported by performance teachers and lecturers and through listening to recordings, although this could create some anxiety: "In China ... when I want to judge if my playing is correct or not I maybe listen to the recordings", but here "I need to know if it's correct or not, so sometimes I'm just worried about this" [S5]. Another student felt that in China, "people ... believe some books or recordings ... [or] what teacher or master told them to do ... here it's got more strong personal ideas about the music" [S6]. Students felt that the programme leader "wants you to create ... your own version and not just follow the opinion of another person" [S4]; this could be effected through a multi-stage process:

I think the first stage is like more copy, or something you need to input in your head, and then you can do some processing thinking and then you can come up with something by yourself, but I think the necessary progress is you need to get a lot of information and then you process. You need to listen more and read more than you could [S6].

Through this process, ideas of correctness and authority in performance could be challenged: "there is space for me to develop the personal character ... I have my own idea about the piece" [S5], whereas "in China we didn't consider that too much, we just conquer the technical problems, play all the notes accurate, play the right rhythms, and then for expressivity just look for teacher's opinion or follow the recording of some CD versions" [S4]. Additionally, in the UK institution, students were encouraged to "contrast different editions ... I have a lot of fun from it, it's interesting" [S5] which could promote intellectual engagement with the material as well as technical and interpretive consideration. This could mean that learning felt less restricted: "compared with China, I feel more freedom here" [S7]; it could also lead to enhanced performance confidence: "I enjoy the process because I can be more confident to stand on the stage because I know the piece well, instead of just singing and I just know the melodies and nothing!" [S8].

However, one participant noted that while a questioning mindset was the norm for her lecturer, it could be otherwise for students: "some international students find it difficult to understand the way of thinking ... some habitual way of thinking will be denied, and get some new way of thinking" [S4]. This was challenging:

I have not much courage for choosing this ... When I'm applying this I need a little bit more time to digest ... it's not easy for me to change the habitual thought ... I spent almost one year for fitting this way of thinking and fitting the atmosphere here [S4].

A singer progressed through these challenges using detailed study of recordings, editions and song texts: "I have to understand how the Western culture would interpret 
the text instead of just my own interpretation" [S8]. She also learnt to question her supervisor's ideas:

[X] says that 'this is right, this is wrong' but ... I look for information on my own, and sometimes I've found [x's] suggestion is quite reasonable after reading, but sometimes I think it may not be true ... I think my conclusion has challenged [x's] thought! [S8].

This created a working relationship in which she could articulate and accept different viewpoints, contrasting with the previous teaching style experienced by another student in China where: "normally we will like to imitate what [teachers] play, but not put forward some challenge ... we just follow the teacher ... not really thinking about what I do that, why the teacher does that ... we just imitate someone in our practice" [S4]. Through extensive reading S8 reached a position that accommodated divergence: "we can't just put our conclusions on one side, sometimes, because there may be possibilities to be on the other side". More research with a larger sample will be useful to determine whether these findings result from particular individual teaching styles, student attitudes towards learning, or other factors.

In both performance and academic studies the differences encountered by these students between practices in the UK and in China were most apparent when engaging with critical thinking. Just one student felt that her Chinese lecturers had been prepared to accept different views, but felt that this was rare: "I know lots of universities are not like this!" [S7]. It was thought that difficulties in engaging in critical thinking resulted from the Chinese education system, and related crucially to undergraduate university entrance: "if you answer critically or on the wrong path you won't get a good result and then you can't enter a good university" [S2]. Students were previously trained to believe that "the contents in books are all right and authoritative" [S9], and to "respect the writer" [S9]; therefore, "no matter where I am, England or China, critical reading is really difficult for me" [S9]. Several students felt that this was stressful: "I always see that word and it gives me a headache! I'm just not used to thinking a lot; I'm still trying to work on it" [S3]. Another student noted that "I never considered those sort of questions before ... my teacher in China didn't, would never ask these questions in this way" [S4].

When asked how they were learning to use critical thinking, one student stated that "the meaning of critical thinking is from the different points of view ... I need to understand why I think this way, and then think from the opposite way" [S5]. Previously, S8 "just grabbed somebody's ideas and ... didn't check a lot of the opposite arguments", but now detailed a more sophisticated awareness:

I think my own idea is also built up from what I have read and how I interpret them, whether they are right or wrong and then I generate my own idea from the resources I have looked at. And so I may have more independent thinking after reading more and looking for more ... now I can think more deeply on a question [S8]. 
This student felt that learning how to develop this approach was inspired by her lecturer:

\begin{abstract}
...when we discuss the commentary he has quite a lot of suggestions and on the direction that I need to think about, so I have different directions, I have more indepth, more meaningful direction to look for, instead of in the past I just depend on my own and then I was thinking about very simple questions and very simple directions, so I think that's the main difference - what I look for, the way that I think was more simple, in the past [S8].
\end{abstract}

Through this process, students could develop originality, although they felt that "it depends on the topic ... if it's a topic that I'm familiar with, I come up with new ideas easily" [S3], and would also depend on the extent of knowledge: "I think I should read more articles, then I can compare these and I can have my thought. I think the most important thing is to gain knowledge from books or experience" [S2]. S3 now felt that she could "just let the books become my references and express my own ideas, using my own knowledge". The importance of originality for academic assessment was recognised: 'we need to prepare what other people say, but the most important thing is to give your opinion, otherwise it's not your essay, it's not valuable' [S7].

Invariably, students described difficulties with the English language which affected both academic work and their social lives. Having previously experienced lecture-style teaching where "you just write notes, you don't need to answer any questions in the class" [S4], even the more confident students with previous experience of overseas study encountered difficulties: "when I came here, I know how to write everything, but just the writing style is different, not just for reference, but everything" [S7]. Although all participants had attended extra language courses they realized that further training was needed and that language problems might not only hinder their own learning but could also impede the progress of others: "sometimes Chinese students not say a lot in class ... we worry about our language ... it's like it's wasting another student's time so it's not very fair for them" [S5]. Some lecturers provided translations of selected vocabulary for Chinese students plus handouts; all helped students to improve their written English, particularly through explaining the meaning and appropriate usage of various words. One student mentioned that her lecturer said "if I speak too fast, just let me know" [S7], but felt that "Chinese students are too shy to stop people's talk" [S7], so she recorded classes: "sometimes you're too nervous to listen when you're in a group and you're the only person who is a foreigner" [S7]. Therefore, coping with language could be emotionally demanding: "there will be something I can't understand ... so that will be anxious for me" [S4].

Participants noted that being in a peer group including students from their countries was both positive and negative: students supported each other, but because "all of us come from the same cultural background" [S5] this hampered learning new ways of thinking as well as development in English language skills. While one student felt that Chinese peers "give me secure feeling ... we can help each other ... it helps me to fit in the life in here" [S4], another said: "I don't want there to be lots of Chinese students here 
... I want to meet a lot of British people ... it has not given me a lot of way to improve my English" [S1]. S2 felt that:

It is good to have many Chinese students in my class, because we know each other very well and our communication would be easier. But I wish to have more English classmates in the class, because Chinese students would rather to speak Chinese when they sit together, so sometimes when we discuss something they might speak Chinese rather than English, so I suppose if we speak more English it might be beneficial to our academic study as well as our English.

S1 also expressed feelings on being part of a cohort which included part-time students, which was a new experience: "I feel so sadly, they are the part-time students and we are the full-time students, and the full-time students are all the Chinese and the part-time are all the British, and because they are part-time they are so busy, we're not together always". However, one student noted that not all of her Chinese peers were studious in the UK - some "spend time in their rooms watching Chinese TV programmes and they're not very close to English culture and everything, and it's just useless and a waste of time. I think it depends on personality" [S7]; additionally, "some students just come here for a year and I think a year's too short to realize lots of things, and if they can't speak English very well, how can they communicate with others? How can they know things?" [S7]. This could be the result of many aspects of culture shock, which students recognized included homesickness, adjusting to commercial opening hours, high living costs, British food and weather, as well as meeting deadlines and time management.

The findings suggest that these participants experienced challenges in adjusting to different ways of thinking and using new learning strategies, particularly in developing critical thinking skills, individuality and self-reliance in interpretation in performance. Students were concerned about their English language skills, and might experience challenges concerning the peer group. The difficulties with language and social factors align with those discussed by Bodycott (2012), who recognized positive and negative values of spending time with co-nationals. However, these students developed increased understanding of different approaches to study and awareness of the potential of informed independent thinking in shaping their written work and performance.

\section{Cultures and future plans}

Student comments reflected the multiplicity of views concerning Chinese and Western music within China and Hong Kong discussed earlier. Although students rated knowledge of both musics, their comments suggest that Western music was prioritized in their home countries: "my generation would think Western is the best, piano or violin is the high level of music" [S7]. This was thought to be because previous generations had promoted Western values and experiences when returning from overseas study. Furthermore, parents might believe that Western instrumental learning could provide more opportunities "for their child to have a better future in the Western side" [S3] as Western 
culture will "broaden my horizon" [S9]. This suggests that a desire for global education may commence long before the years of higher education.

Three students who had learned traditional Chinese instruments no longer played them in the UK: "when I come here I need to study Western things like piano ... I'm not in China, I'm in England" [S1]. Although one student was recording Chinese instruments for her music technology MA, and some acknowledged that a UK audience might respond positively to performance of traditional Chinese instruments and that peers might be interested in establishing a Chinese music society, the comments from the others suggest separation, rather than integration of cultural experience during MA study. This could result from perceptions that UK study should have a Western focus, that Western music would lead to more opportunity, and also result from the pressures of time felt by most students. Nevertheless, the participants recognized that other students and staff were interested in their culture, which was supported by the department's collection of Chinese instruments. This research also demonstrated that their views were valued.

Finally, students articulated their thoughts on progression. While most were going back to China or Hong Kong, one student was planning to begin a PhD at the same university and another was seeking employment in the UK, feeling that "it's a better atmosphere, for working ... I think it feels less pressure as well" [S3]. Although several others had hoped to begin doctoral programmes, MA study had enabled a more realistic understanding of the difficulties of finding a suitable topic for further study, of academic demands, and financial pressures. One student hoped to obtain work in arts administration in China and to save for future study in music therapy (identifying it as undeveloped in China); another recognized that her academic limitations meant that further study was currently unrealistic.

Students mentioned the importance of contacts as well as qualifications in obtaining university teaching positions; while a UK qualification would help, the Chinese and Hong Kong job markets are very competitive. Performance combined with teaching might be a starting point. Those returning home noted the additional expectation of marriage and starting a family; one student felt that "it's the only chance in my life to see what I want to see" [S7], and was therefore delaying her return. It was also stated that UK study enabled students to widen their job prospects in China through not only academic qualifications but also enhanced English skills; this could facilitate work as an agent or interpreter. The UK experience also changed personal ambition: one student noted that "before I came here I want to find a job in China, I want to be the best, top level of people working in China, but now l'd say the whole world" [S7]. 


\section{Discussion}

Participants articulated many positive aspects of studying at a UK university including small group tuition, provision of staff support, individual feedback and expansion of performance repertoire. While difficulties were acknowledged including the development of informed independent thinking, participants noted the development of new learning strategies, expansion of repertoire knowledge and the value of the experience.

Various observations emerge from the data which warrant further discussion. The findings relating to programme choice and "push-pull" factors (MAZZAROL; SOUTAR, 2002; BODYCOTT, 2012), and to the authenticity of gaining knowledge of Western music from Western authorities align with and expand those of previous research on internationalization; these students also value the relative acceleration of progress, academically, temporally and financially, compared to that of peers continuing their education in the home country, and the related hope for enhanced career prospects. However, comments from students who identified challenges adjusting to different academic practices while also attempting to adapt to the demands of a different language and living in a new country indicate concerns relating to capacity to assimilate knowledge and to achieve academic and instrumental/vocal performance competence. The pressures that students previously experienced to complete their degree courses in China with a good result in order to study in the UK now become pressure to simply pass their MA; student comments suggest that those without prior overseas study experience are likely to encounter many challenges during this relatively short period of study. These findings align with those of Quan, He and Sloan in regard to Chinese students studying one-year taught Business and Management MSc programmes in the UK (2016). These authors additionally note the importance of pro-active behaviour in negotiating a four-stage transition process: pre-departure, first arrival, adjusting after the first four weeks to the start of semester 2, and then achieving competence from the middle of semester 2.

Isolation and over-reliance on co-nationals within peer groups (QUAN; HE; SLOAN, 2016; SKYRME; MCGEE, 2016) are identified as impacting on progression during the period of study; however, these factors may also influence choice of programme. Quan, He and Sloan emphasize the importance in the pre-departure stage of active engagement with information concerning the choice of overseas institution, rather than "over-reliance on agents" (2016 p.334), which "deprived students of valuable opportunities to understand the British education system, institutions and variety in different subject areas" (ibid); this aligns with the influence of recommendations and agents identified by Mazzarol and Soutar (2002). Bodycott (2012) details misapprehensions of parents on the outcome of overseas study such as possibility for subsequent immigration and freedom of travel between the new location and China; views on institutions and programmes need substantiation through research-informed evidence. A related strand worthy of further investigation would be the means by and extent to which students are informed not just about institution and programme, but also about programme content, modes of delivery, assessment and expectations relating to learner engagement; this may have 
implication for the development of information and support strategies in both home and destination countries.

Skyrme and McGee highlight corresponding challenges for teachers which relate to teacher-positioning in relation to student-centred pedagogy; despite the work of Esslin-Peard and Shorrocks (2018) on the value of reflection for Chinese MMus students in a UK university learning string instruments there is little information to date on how UK teachers and international students negotiate potentially different practices in both academic and performance learning in higher Music education. Esslin-Peard and Shorrocks found that instruction in maintaining a practice diary and writing reflective, self-critical essays appear beneficial for instrumental music learning, with effective transfer of practice strategies and the ability to "identify and address problems effectively" applied by Chinese students to learning a second Western instrument (2018, p.35). Students in the current research noted the novelty and value of specific, individual feedback on their essays and performance; one student also felt emboldened to challenge the views of the lecturer, which suggests development of learner orientation towards active and critical engagement. Investigating how Music students are supported to become questioning practitioners, able to voice and discuss divergent views, connects to the work of Brand (2006) in the Hong Kong context, and suggests scope for further development of pedagogy in both home and destination countries to promote understanding of strategies to support student voice as well as understanding of the scope and benefits of Music programmes.

While it might seem logical to assume that Western institutions could convey greater authenticity in relation to Western instrumental and vocal music, conferred through pedagogical encounters with historic instruments, guidance on musicological and historically-informed performance practice and performance scholarship, more information is needed about the realities of this pedagogy in relation to teaching and learning. How do UK teachers adapt pedagogical content and delivery to relate to students' prior knowledge for those coming from a culture with potentially different orientations to the same material? How do students engage with this learning process, which appears to require them to negotiate moving from familiar instructive and conformist pedagogies, both in classrooms and in master-apprentice modes of instrumental and vocal teaching, to individual and critically-engaged positions? Would a student be able to develop this learning when they return to China, and will this knowledge have relevance? In a conformist culture, identified by these participants as one in which students tend to produce similar performances to those of peers, what are the implications for performance reception if a performer presents different qualities and interpretation from the norm? Additionally, would the practices of UK study subsequently affect students as performance teachers in China? These questions are worthy of research.

Finally, the challenges of academic practices may have implications for learner agency as well as learner enjoyment: do Chinese students have agency within their learning in the UK, and if so, what forms does it take? Students in this research appear to have largely relinquished their Chinese instruments, despite the potential for these 
providing mastery and agency in extra-curricular performance domains; while this may have been a culturally adaptive strategy involving separation rather than integration, creating study time for Western instrumental and academic learning, there are implications for self-identity and for pedagogical connections between different musical practices which could be usefully explored in future research. Lindgren and McDaniel propose that "the most transformative learning experiences will be those that are directed by the learner's own endeavors and curiosities" (2012, p.345). Research has yet to discover how these might manifest for international Music students in the UK; whether the focus of transformative learning concerns negotiating academic and instrumental/ performance practices or extends to generating and exploring unique conceptual or performative questions, a topic which could usefully be investigated with all students. This may build on knowledge concerning ways in which international students might be "disadvantaged" and "differentiated" in comparison to home students (HOLMES, 2004, p.303) which could relate to prior learning orientation as well as to adaptation to study in the overseas institution, and therefore might subsequently enable the creation of new pedagogical practices to support their transformative development. Therefore, a number of further research areas concerning the potential afforded by internationalization are indicated, which could support further pedagogical development.

\section{Conclusion}

Despite the small sample size precluding generalizable findings, there are implications for educators, including the need to understand students' cultural backgrounds and to learn about educational approaches, values and experiences within these; to recognize the need for emotional support within a mentoring-style supervisory relationship, in which students are given individual feedback which also helps them understand their own approaches to learning; to consider how students are supported in developing informed independent thinking; to consider the influence and contribution of the co-national peer group; and to consider the impact of separation or integration of musical practices from students' home countries. There is scope for further research to explore whether the findings of this study would correlate with other students' observations of differences between undergraduate and postgraduate study in China and Hong Kong or whether the differences experienced by these participants are the result of encountering new pedagogical practices in the UK. Further research is also needed to explore teaching styles in academic and performance contexts, processes of adjustment made by teachers and students, and cultural perceptions, which have considerations for authenticity and agency and the development of transformative pedagogy. Research-informed awareness of these aspects may contribute to further enhancing the capacity of Chinese students to realize the aims of their government in relation to "global vision" and international participation (HUANG, 2016, p.184); they may also create pedagogical developments of benefit to students and teachers in both home and overseas institutions. 


\section{Acknowledgments}

The author would like to thank the music students who participated in this research.

\section{References}

BODYCOTT, P. Embedded culture and intercultural adaptation: Implications for managing the needs of Chinese students. Journal of Higher Education Policy and Management, v. 34, n. 4, p. 355-64, 2012.

BRAND, M. Hong Kong music teachers ask: "Does music education research matter?" Bulletin of the Council for Research in Music Education, No. 169, p. 79-86, Summer 2006.

BRAUN, V.; CLARKE, V. Using thematic analysis in psychology. Qualitative Research in Psychology, v. 3, n. 2, p. 77-101, 2006.

$\mathrm{CHOI}, \mathrm{J} . \mathrm{H}$. Attitudes of international music students from East Asia toward US higher education institutions. International Journal of Music Education, v. 31, n. 3, p. 346-58, 2012.

COLLEY, B. D.; EIDSAA, R. M.; KENNY, A.; LANG, B. W. Creativity in partnership practices. In: MCPHERSON, G. E.; WELCH, G. F. (Eds.). The Oxford handbook of music education, volume 2. Oxford: Oxford University Press, 2012, p. 409-425.

COMEAU, G.; HUTA, V.; LIU, Y. Work ethic, motivation, and parental influences in Chinese and North American children learning to play the piano. International Journal of Music Education, v. 33, n. 2, p. 181-94, 2015.

COVERDALE-JONES, T.; RASTALL, P. (Eds.). Internationalising the university: The Chinese context. Basingstoke: Palgrave Macmillan, 2009.

EDWARDS, V.; RAN, A. Building on experience: Meeting the needs of Chinese students in British higher education. In: COVERDALE-JONES, T.; RASTALL, P. (Eds.). Internationalising the university: The Chinese context. Basingstoke: Palgrave Macmillan, 2009, p.185-205.

ESSLIN-PEARD, M.; SHORROCKS, T. The role of reflective practice in learning a second instrument $a b$ initio in adulthood: A pilot study with Chinese M Mus students in higher education. In Himonides, E.; King, A.; Cuadrad, F. (Eds). Proceedings of the Sempre MET2018, London: University of London, 35-37, 2018. Retrieved from: https://www. 
researchgate.net/publication/324065475_Proceedings_of_the_Sempre_MET2018_ Researching_Music_Education_Technology

EVANS, C. C. A view from the dormitory: The Shanghai Conservatory of Music. Chime, v. 8, p. 104-112, 1995.

HEFCE (Higher Education Funding Council for England), (2014). Retrieved from: https://webarchive.nationalarchives.gov.uk/20180319132246/http://www.hefce.ac.uk/ news/newsarchive/2014/Name,94021,en.html

HEFCE (Higher Education Funding Council for England), (2019). Retrieved from: www. hefce.ac.uk

HESA (Higher Education Statistics Agency), (2014). Retrieved from: www.hesa.ac.uk

HESA (Higher Education Statistics Agency), (2019). Retrieved from: https://www.hesa. ac.uk/news/17-01-2019/sb252-higher-education-student-statistics/location

HO, W. C. Educational development according to quality, commercialisation and internationalisation: A study of music faculties at Hong Kong universities. Music Education Research, v. 3, n. 2, p. 187-202, 2001.

HO, W. C. Music education curriculum and social change: A study of popular music in secondary schools in Beijing, China. Music Education Research, v. 16, n. 3, p. 267-89, 2014.

HO, W. C.; LAW, W.-W. Challenges to globalisation, localisation and Sinophilia in music education: A comparative study of Hong Kong, Shanghai and Taipei. British Journal of Music Education, v. 23, n. 2, p. 217-37, 2006.

HO, W. C.; LAW, W.-W. Sociopolitical culture and school music education in Hong Kong. British Journal of Music Education, v. 26, n. 1, p. 71-84, 2009.

HOLMES, P. Negotiating differences in learning and intercultural communication: Ethnic Chinese students in a New Zealand university. Business Communication Quarterly, v. 67, n. 3, p. 294-307, 2004.

HUANG, H. Why Chinese people play Western classical music: Transcultural roots of music philosophy. International Journal of Music Education, v. 30, n. 2, p. 161-76, 2012.

HUANG, L. Co-curricular activity-based intercultural competence development:

Students' outcome of internationalisation at universities. Innovations in Education and Teaching International, v. 54, n. 3, p. 184-193, 2016. 
LAW, W.-W.; HO, W. C. Music education in China: In search of social harmony and Chinese nationalism. British Journal of Music Education, v. 28, n. 3, p. 371-88, 2011.

LEONG, S. Mentoring and research supervision in music education: Perspectives of Chinese postgraduate students. International Journal of Music Education, v. 28, n. 2, p. 145-58, 2010.

LEUNG, B. W.; MCPHERSON, G. E. Students' motivation in studying music: The Hong Kong context. Research Studies in Music Education, v. 32, n. 2, p. 155-168, 2010.

LEUNG, B. W.; MCPHERSON, G. E. Case studies of factors affecting the motivation of musical high achievers to learn music in Hong Kong. Music Education Research, v. 13, n. 1, p. 69-91, 2011.

LI, L.; RIVERS, G. J. An inquiry into the delivering of a British curriculum in China. Teaching in Higher Education, v. 23, n. 7, p. 785-901, 2018.

LINDGREN, R.; MCDANIEL, R. Transforming online learning through narrative and student agency. Educational Technology \& Society, v. 15, n. 4, p. 344-355, 2012.

MAZZAROL, T.: SOUTAR, G. Push-pull factors influencing international student destination choice. International Journal of Educational Management, v. 16, n. 2, p. 8290 .

MCMAHON, P. Chinese voices: Chinese learners and their experiences of living and studying in the United Kingdom. Journal of Higher Education Policy and Management, v. 33, n. 4, p. 401-414, 2011.

PETERSEN, S. Talent development in Chinese and Swiss music students. International Journal of Music Education, v. 36, n. 2, p. 230-243, 2018.

QUAN, R.; XINMING, H.; SLOAN, D. Examining Chinese postgraduate students' academic adjustment in the UK higher education sector: A process-based stage model. Teaching in Higher Education, v. 21, n. 3, 326-343, 2016.

RASTALL, P. Cooperation with Chinese universities - issues and trends. In: COVERDALE-JONES, T.; RASTALL, P. (Eds.). Internationalising the university: The Chinese context. Basingstoke, UK: Palgrave Macmillan, 2009, p. 1-10.

SKYRME, G.; MCGEE, A. Pulled in many directions: Tensions and complexity for academic staff responding to international students. Teaching in Higher Education, v. 21, n. 7, p. 759-772, 2016. 
UKCISA (UK Council for International Student Affairs) (2014). Retrieved from: http:// www.ukcisa.org.uk/Info-for-universities-colleges--schools/Policy-research-statistics/Research--statistics/International-students-in-UK-HE/

WANG, L. Chinese students, learning cultures and overseas study. Basingstoke: Palgrave Macmillan, 2015.

WATERS, S. Sharing global musics: Preserving the past, preparing for the future - a look at music education in China. Music Educators Journal, v. 101, p. 25-27, 2014.

WATKINS, D. A.; BIGGS, J. B. The Chinese learner: Cultural, psychological and contextual influences. Hong Kong: Comparative Education Research Centre and the Australian Council for Educational Research Ltd., 1996.

WATKINS, D. A.; BIGGS, J. B. Teaching the Chinese learner: Psychological and pedagogical perspectives. Hong Kong: Comparative Education Research Centre and the Australian Council for Educational Research Ltd., 2001.

WHITBREAD, R. G.; LEUNG, S. Music education and the culture of assessment: A Hong Kong secondary school perspective. Asia-Pacific Journal for Arts Education, v. 9, n. 2, n.p, 2011. Retrieved from: http://www.ied.edu.hk/cca/apjae/Vol9_No2.pdf

WONG, M. W. Y. Music lessons in the elementary schools of Vancouver and Hong Kong. Asia-Pacific Journal for Arts Education, v. 1, n. 1, p. 27-41, 2002.

XIE, J.; LEUNG, B. W. Students' motivation to study music: The mainland China context. Research Studies in Music Education, v. 33, n. 1, p. 59-72, 2011.

YAKABOSKI, T.; RIZZOLO, S; OUYANG, L. Understanding Chinese students' college choice to increase Chinese student recruitment: A focus on music majors. TeacherScholar: The Journal of the State Comprehensive University, v. 8, Article 2. Retrieved from: http://scholars.fhsu.edu/ts/vol8/iss1/2

YANG, Y.; WELCH, G.; SUNDBERG, J.; HIMONIDES, E. The challenges inherent in promoting traditional folk song performance and pedagogy in Chinese higher education: A case study of Hua'er. Conference paper: 29th ISME World Conference, Beijing 1-6 August, 2010. Retrieved from:

https://www.researchgate.net/publication/267270896_The_challenges_inherent_in_ promoting_traditional_folk_song_performance_and_pedagogy_in_Chinese_higher_ education_A_case_study_of_Hua'er 
YIN, H.; HAN, J; LU, G. Chinese tertiary teachers' goal orientations for teaching and teaching approaches: The mediation of teacher engagement. Teaching in Higher Education, v. 22, n. 7, p. 766-784, 2017. 